\title{
INICIATIVAS DE REVITALIZACIÓN DE LA LENGUA INDÍGENA EN CANADÁ(1)
}

\section{INDIGENOUS LANGUAGE REVITALIZATION INITIATIVES IN CANADA}

\author{
José Zarate(2) \\ Programa de Desarrollo de los Pueblos Indígenas \\ Primate's World Relief and Development Fund (PWRDF). Canadá
}

"La lengua es uno de los principales instrumentos para transmitir la cultura de una generación a otra y para comunicar sentido y dar sentido a la experiencia colectiva. Las lenguas aborígenes sufrieron un duro golpe durante la época en que la política escolar obligaba a todos los niños a hablar inglés o francés". (3)

"Creemos que es hora de que Canadá reconozca que su herencia lingüística es más profunda que los idiomas inglés y francés. Son, de hecho, las historias orales, las historias de la creación las que explican cómo los primeros pueblos llegaron a estar en esta tierra, milenios antes que los franceses o los ingleses, y las canciones y bailes que hablan de nuestra conexión con la tierra que dan este tejido. La textura y vitalidad únicas que la hacen diferente a cualquier otra tela en el mundo. Estos tesoros nacionales deben protegerse para las generaciones futuras". (4)

(1) Traducción de la nota redactada originalmente en inglés: Pável H. Valer Bellota y Luz A. Ramos Ayala.

(2) Coordinador del Programa de Desarrollo de los Pueblos Indígenas del Primate'sWorldRelief and DevelopmentFund (PWRDF) de la Iglesia Anglicana de Canadá.Peruano, miembro por adopción de la Nación Nisga'a de Columbia Británica. Condecorado con la Pluma de Águila de la Nación Mi'kmaq de Nueva Escocia, Canadá. Email: indigenousworld@gmail.com

(3) Comisión Real de Pueblos Aborígenes (1996). Aspectos destacados del informe de la Comisión Real de Pueblos Aborígenes. Ministro de Abastecimiento y Servicios de Canadá. Gobierno de Canadá.

(4) Grupo de trabajo sobre lenguas y culturas aborígenes (2005). Hacia un nuevo comienzo Informe fundacional de una estrategia para revitalizar las lenguas y la cultura de las Primeras Naciones, los Inuit y los Métis. Herencia canadiense. Gobierno de Canadá. pág. 166. 
"Una lucha común que enfrentan los pueblos indígenas que dejaron sus lejanas comunidades rurales andinas para vivir en Lima en busca de una 'vida mejor'ha sido el acceso a la igualdad de derechos. Muchos de ellos decidieron dejar de hablar quechua, su lengua materna, evitar usar sus ropas indígenas regionales, practicar sus celebraciones y creencias tradicionales para proteger a sus hijos, familiares y a ellos mismos del racismo y la discriminación ${ }^{\prime \prime(5)}$

Para los pueblos indígenas de Canadá, sus lenguas indígenas representan una parte importante de la cultura, la identidad y el bienestar general de las personas, las familias y las comunidades. El Censo de Población de 2016 estimó la población de identidad indígena en 1.673.785, aproximadamente el 4,9\% de la población total de Canadá. Con respecto al uso de lenguas indígenas, las políticas del gobierno canadiense de 1879 a 1986 aceleraron enormemente el peligro, pues su objetivo era erradicar sistemáticamente las lenguas, culturas, religiones, identidades y comunidades indígenas. Se establecieron escuelas financiadas por el gobierno, administradas por iglesias, y los niños indígenas fueron matriculados por la fuerza. En estas escuelas, los niños fueron sometidos a todo tipo de actos abusivos, incluida la prohibición de hablar su lengua materna. Los estudiantes que desobedecían eran castigados. El sistema de escuelas residenciales"hizo obligatoria la integración en la cultura dominante y sentó las bases para el lingüicidio de las lenguas aborígenes. Rompió el vínculo entre padres e hijos impidiendo la transmisión natural del idioma y la cultura a la próxima generación".(6)

Una de las historias que merece ser compartida es la de la Nación Tlicho de los territorios del noroeste, a través de su proyecto educativo y cultural "Los Senderos de Nuestros Ancestros", promovido por la junta escolar local, comenzó con solo cinco canoas, treinta personas y ahora es un proyecto independiente que promueve el viaje de 150 personas y la participación de aproximadamente 1.000 personas más, una multitud acogedora, cuando los viajes llegan al final de su viaje "en la selva". A los jóvenes que participan en este proyecto se les reconoce créditos en sus cursos de secundaria por su experiencia. La junta escolar ha incorporado este proyecto en el plan de estudios de la escuela. Los Tlicho solían escuchar las historias de los ancianos sobre la tierra y luego sobre los lugares donde vivían y los ríos y senderos que seguían. Ahora, a través de los senderos de sus antepasados, los Tlicho han podido revivir y afianzar esta tradición ancestral al llevar a los jóvenes a la tierra para aprender nombres de plantas, medicinas, conocer el clima, características de animales y peces y visitar las tumbas de los ancestros. En los cementerios tradicionales recuperan cantos y ceremonias del pasado.

(5) Reflexión personal del autor de esta nota, hijo de madre quechua de Huancavelica y padre quechua de Cusco, Perú.

(6) Esfuerzos de revitalización de la lengua indígena Mohawk en Canadá - McGillJournal of Education - Vol. 54 No. 1 Invierno 2019. 
Otra iniciativa es de la nación Nuu-chah-nulth (NCN) de Columbia Británica que ha venido implementando el Programa Cultural de Preservación y Promoción de la lengua y cultura Nuu-Chah-Nulth (NLCP) para las generaciones actuales y futuras entre sus 14 comunidades. Durante los últimos 150 años, el pueblo NuuChah-Nulth enfrentó muchos desafíos para la continuidad y supervivencia de su idioma y cultura. Como consecuencia grave de los golpes y la ridiculización de los estudiantes de las escuelas residenciales por hablar su lengua materna, el idioma Nuu-Chah-Nulth que alguna vez se hablaba en las comunidades ha sido reemplazado principalmente por el inglés. Desde que se dio inicio al NLCP se han producido muchos efectos positivos; algunas comunidades han iniciado campamentos de inmersión lingüística y proyectos de desarrollo de recursos, así como algunas herramientas educativas que desarrollaron como diccionarios, aplicaciones, sitios web, libros y actividades de aprendizaje tradicionales y culturales en las escuelas; es decir, bailes, música y artes.

Del mismo modo, la nación Mohawk de Quebec ha venido desarrollando programas de idiomas y cultura dirigidos a sus niños, jóvenes y estudiantes adultos en general, así como a personas externas a la comunidad de Kahnawake. Una de sus iniciativas estelares es un innovador programa de títeres que ha ganado varios premios canadienses e internacionales. Este programa comunitario de idiomas y títeres, llamado Tótatánon Ohkwári Kanien'kéha Puppet Show, ha contribuido a aumentar las habilidades y capacidades, así como a fomentar la competencia oral y las habilidades literarias en su lengua materna a niños de seis años o menos, así como como para los estudiantes adultos. El programa innovador de títeres se presentó en Ginebra en diciembre de 2019.

El trasfondo histórico concreto de los esfuerzos de la comunidad Mohawk para la supervivencia de su idioma comienza en 1977. Un grupo de Kahnawakero (no ciudadanos Mohawk) preocupados y comprometidos se reunieron para discutir los intereses y necesidades de preservar y mantener activamente el idioma único de Kahnawake como patrimonio cultural para que continúe prosperando en su comunidad para las generaciones venideras. A fines de 1990, algunos ancianos de Kahnawake se dieron cuenta de que su idioma estaba en peligro porque generaciones de familias habían crecido sin hablar el idioma Mohawk. Estos ancianos actuaron una vez más para desarrollar una ley que reconozca al Kanien'kéha (Mohawk) como el idioma oficial de Kahnawake con la esperanza de que algún día regrese como el idioma principal utilizado en toda la comunidad. Luego, el Consejo Mohawk de Kahnawake promulgó la Ley del idioma Kahnawake el 20 de diciembre de 1999. Esta ley exige el resurgimiento y restauración de Kanien'kéha como el idioma principal de comunicación, educación, ceremonia, gobierno y negocios dentro de Kahnawake. Si bien otorga a todas las personas de la comunidad el derecho a recibir servicios, trabajar y recibir educación en otro idioma, la ley también establece que las instituciones públicas y las empresas de 
Kahnawake tienen la obligación moral y ética de proteger, promover y alentar el uso de su lengua.

Por último, podemos citar al Consorcio de Educación Superior y de Adultos de las Primeras Naciones (FNAHEC) de Alberta, cuya misión es coordinar la revitalización de la lengua, la cultura y la historia de Siksika (Blackfoot). FNAHEC se incorporó en 1997 para dar a las universidades de las Primeras Naciones de Alberta una voz colectiva y una estrategia coordinada para revitalizar y mantener el Siksika. Los miembros de la universidad FNAHEC tienen muchos cursos desarrollados localmente que abordan sus respectivas culturas y experiencias. Por ejemplo, Old Sun Community College (OSCC) ha desarrollado 37 cursos de Estudios Siksika y continúa desarrollando otros a medida que surge la necesidad. FNAHEC ha seguido compartiendo cursos que ha desarrollado con la academia, la comunidad Siksika y ONGs. También continúa digitalizando materiales para documentar, preservar y transmitir el conocimiento del idioma y la cultura Siksika/Blackfoot. El OSCC ha negociado con éxito la adquisición de las copias digitales de la historia de Blackfoot en poder de los Archivos del Gobierno de Alberta. Esto tiene grandes implicaciones para la preservación de la historia y el idioma de Siksika. También planea fortalecer la investigación de FNAHEC, el desarrollo curricular y la implementación de cursos y proyectos de idiomas y cultura.

Para finalizar, las comunidades indígenas cuyas historias son mostradas en este artículo han brindado un fuerte mensaje al autor, la preservación y difusión de su lengua y su cultura indígena son fundamentales para su recuperación, bienestar y supervivencia. Esperemos que en los próximos años, bajo los auspicios de la ONU que declaró el Decenio Internacional de las Lenguas Indígenas hasta 2022, los pueblos indígenas del mundo logren, mejoren o aumenten el reconocimiento y la aceptación de parte de cualquier nivel de gobierno en sus países-Comunidad, Municipal, Provincial y Federal- de su lengua indígena como lengua adicional en el tratamiento de todos los asuntos comerciales y oficiales de la comunidad. Además, esperemos que los pueblos indígenas logren o estén cerca de ese objetivo, que las agencias gubernamentales de su comunidad, es decir, la educación, los servicios sociales, etc., se brinden en su idioma originario. Tiempos emocionantes, sigamos caminando al lado de los pueblos indígenas como iguales y juntos para celebrar sus éxitos, una fuente de aprendizaje de su visión y sabiduría. 